\title{
Geografiniai žemėnaudos kaitos tyrimai Lietuvoje: raida, kryptys, perspektyvos
}

\section{Darijus Veteikis,}

\section{Eglè Piškinaitė}

Vilniaus universitetas,

Geomoksly institutas,

M. K. Čiurlionio g. 21/27,

03101 Vilnius

El.paštas: darijus.veteikis@gf.vu.lt; episkinaite@gmail.com
Veteikis D., Piškinaitė E. Geografiniai žemènaudos kaitos tyrimai Lietuvoje: raida, kryptys, perspektyvos. Geologija. Geografija. 2019. T. 5(1). ISSN 2351-7549.

Straipsnyje analizuojami per 1954-2018 m. atlikti žemès naudmenų / žemès dangos kaitos geografiniai (apimantys teritorinị aspektą) tyrimai Lietuvoje. Atliekant analizę buvo sistemingai gilintasi ị Lietuvos ir užsienio autoriu publikacijas, Vilniaus universiteto (VU) studentų baigiamuosius darbus. Išryškejo skirtingos analizuojamos temos darbų tyrimo dimensijos ir laikotarpiai, reprezentuojami daugelio ịvairių specialistų - geografų, žemètvarkininkų, žemès ūkio specialistų. Atlikus VU studentų baigiamụjų darbų analizę, parengta darbų, nagrinejjančiu žemėnaudos kaitą, aprẻpties kartoschema. Paaiškeejo, kad atliekamų žemėnaudos kaitos tyrimų kiekis yra susijęs su politiniais, socialiniais, ekonominiais pokyčiais šalyje, kurie lemia ir akivaizdžius žemėnaudos pokyčius, ir kintantị publikacijų nagrinejama tematika skaičių. Daugiausia tyrimų yra aprašomojo pobūdžio ir apima sąlyginai neilgus 10-20 metų laikotarpius. Studentų baigiamieji darbai dažniausiai orientuoti ị lokalinius žemės naudmenų struktūros kaitos tyrimus. Atsižvelgiant i Europos žeménaudos kaitos tyrimų tendencijas, siūlytina ị Lietuvos geografinius žemès naudmenų tyrimus ịtraukti mažai ištirtus kraštovaizdžiu tipus ir vietoves, identifikuoti svarbiausius kraštovaizdžio kaitos veiksnius, tobulinti kiekybinès kraštovaizdžio kaitos analizès metodus, vykdyti tyrimus, apimančius ilgesnius istorinius laikotarpius ir tarpvalstybinius regionus, ieškoti bei atsižvelgti ị subtilius ir naujus kraštovaizdžio procesus, tyrinèti stabilias, mažai besikeičiančias žemènaudos struktūras, padėsiančias nustatyti veiksnius, atsparius išorès poveikiui.

Raktažodžiai: žemėnauda, žemės naudmenų struktūra, žemės danga, žemės naudmenų struktūros kaita, kraštovaizdžio kaita

\section{IVADAS}

Tiek žemès naudmenos (teritorija su paskirtimi, kurią suteikia žmogus), tiek žemès danga (žemès naudmenų fizinè išraiška žemès paviršiuje) geografijos moksle laikomi tyrimų objektais, svarbiais socialiniu, ekonominiu, kraštovaizdžio morfologijos ir funkcionavimo bei aplinkos apsaugos požiūriu. Žemés naudmenų / žemès dangos (toliau - žemènaudos) struktūra konkrečiu gamtinių sąlygų fone kinta dèl ekonominių, politinių, kultūrinių ir kitų visuomenès veiksnių, kuriuos ji savo ruožtu gali veikti ir grị̌tamuoju būdu (Hartvigsen, 2014), todèl jos fiksavimui reikalinga nuolatinè stebėsena. Tokie pokyčių stebejimai leidžia ne tik atpažinti kraštovaizdžio raidos 
dèsningumus, bet ir ịvertinti veiksnių, darančių itaką kraštovaizdžiui, mastą, prognozuoti galimas kraštovaizdžio kaitos kryptis ir užkirsti kelią destrukciniams procesams (Ribokas, 2011).

Sudètingi pokyčiai šalies kraštovaizdyje, pasireiškiantys dèl aktyvaus bioprodukcinio (žemès, miškų, žuvininkystès) ūkio vystymosi, urbanizacijos pletros, atskirų regionų depopuliacijos ir dèl to vykstančios renatūralizacijos procesų tampa aktualūs šalies valdymą organizuojančioms institucijoms, suinteresuotoms tvariu krašto vystymusi, taip pat patraukia ir tyrèjų dèmesî, todèl nuolatos daugèja darbų, skirtų kraštovaizdžio arba konkrečiai žemès naudmenų / žemès dangos pokyčiams apibūdinti ir nustatyti.

Kadangi žemès naudmenos yra ūkinès veiklos produktas bei erdvinis pamatas ir tiesiogiai prisideda prie šalies ekonominio potencialo bei gyventojų socialinès struktūros formavimo, jų tyrimas aktualus visuomenès geografams, ekonomistams, žemès ūkio specialistams, ir šios pakraipos geografinių darbų Lietuvoje yra nemaža grupè. Kita vertus, žemès naudmenos yra ir kraštovaizdžio dalis, technosferos komponentas (Basalykas, 1986; Kavaliauskas, 1992; Kavaliauskas, Veteikis, 2004), talpinantis savo struktūroje ir nemažą klodą mūsų kultūros istorijos, paveldo, taip pat darantis ịtaką teritorijos ekologinei pusiausvyrai. Lietuvoje turime daug darbų, orientuotų ir ị žemès naudmenų arba jų fizinès išraiškos - žemès dangos - tyrimus, kuriuos vykdè kraštovaizdžio geografai, ekologai ir dalis žemès ūkio mokslų atstovų. Pažymètina, kad ši dvilypè ekonominè-ekologinè žemènaudos struktūros esmè suprantama daugelio autorių, todèl minèti du požiūriai darbuose neretai persipina.

Vykdant Europos kraštovaizdžio konvencijos direktyvas, valstybinių institucijų (Aplinkos ministerijos, Aplinkos apsaugos agentūros) iniciatyva Lietuvoje stengiamasi reguliariai atlikti kraštovaizdžio kaitos stebėseną. Šiuo metu yra atlikta žemès dangos struktūros pokyčiu analizè 100 etaloninių vietovių $\left(2,5 \mathrm{~km}^{2}\right.$ ploto kvadratai, mastelis $1: 10$ 000) nuo 1976-1986 (sovietmečio pabaiga) iki 2005-2006 ir 2012-2013 m. (Kraštovaizdžio struktūros ..., 2008; 2015).

Nuo 1995 m. vykdomi bendri Lietuvos Respublikos aplinkos ministerijos, Aplinkos apsaugos agentūros ir Europos aplinkos agentūros CORINE žemès dangos projektai. Lietuvos žemès dangos duomenų bazè yra kuriama ir kas penkeri šešeri metai atnaujinama visoms Europos Sajungos šalims bei šalims kandidatėms (Lietuvos teritorijos yra 1995, 2000, 2006, 2012 ir 2018 m. erdviniai CORINE duomenys) (www.aplinka.lt). Dešifruojant kosminius vaizdus gauti erdviniai žemès dangos duomenys pateikia svarbią informaciją apie šalies žemès dangos būklę bei jos struktūrą, yra palyginami su kitų Europos šalių analogiška informacija ir gali būti panaudojami moksliniuose tyrimuose, tačiau dèl palyginti smulkaus mastelio (1: 100 000) turi apribojimų analizuojant kraštovaizdžio struktūrą ir jos pokyčius lokaliu lygmeniu (Bauža ir kt., 2008).

Oficiali ir aktuali valstybinè informacija apie žemès naudmenas (žemėnaudos struktūrą) kaip dalis Georeferencinio pagrindo kadastro yra valdoma Lietuvos Respublikos žemès ūkio ministerijos (iki 2017 m. gruodžio 31 d. - Nacionalinès žemès tarnybos prie Žemès ūkio ministerijos) ir prieinama per interneto portalą www.geoportal.lt, tačiau visi (visą teritoriją dengiantys ir visus žemès naudmenų tipus apimantys) duomenys yra tik nuo 2010 m., be to, laisvai pasiekiami tik aktualūs (naujausi duomenys). Minètame interneto portale laisvai pasiekiami yra ir aktualūs Lietuvos Respublikos teritorijos apleistų žemių erdviniai duomenys.

Moksliniai žemès naudmenų struktūros tyrimai, vykdomi šalies mokslo įstaigose, neturi vieningo koordinavimo, todèl yra didelè chronologinè, geografinè ir tematine darbų įvairové, kurią šiame straipsnyje apžvelgti ir apibendrinti. Straipsnyje taip pat apžvelgiama ir atliktų tyrimų teritorinè sklaida bei identifikuotos teritorijos, kurioms žemènaudos tyrimai turètų būti aktualūs, atkreipiamas dèmesys i perspektyvias žemènaudos tyrimu kryptis.

Straipsnyje visų pirma nagrinėjami Lietuvoje ir užsienyje atlikti bei paskelbti moksliniai darbai, skirti mūsų šalies žemènaudos kaitos tyrimams. Palyginimui apžvelgiamas ir kaimyninių šalių tyrimų spektras nagrinejjama tematika. Žemènaudos struktūros tyrimus reprezentuoja ir studentų darbai, todèl straipsnyje pateikiamas Vilniaus universiteto geografijos studentų baigiamuju darbų žemès naudmenų tematika apibendrinimas su nustatyta šių tyrimų geografine aprèptimi šalies ribose. 


\section{DARBO METODIKA}

Rengiant straipsni buvo koncentruojamasi $\mathfrak{i}$ erdvinį žemès naudmenų kaitos aspektą sistemingai analizuojant Lietuvos ir užsienio autorių publikacijas, o darbų palyginimui teminès, teritorinès bei chronologinès apimties požiūriu - ir Vilniaus universiteto (VU) studentų baigiamuosius darbus. Vykdyta Lietuvoje leidžiamuose moksliniuose žurnaluose "Geografijos metraštis“ ir "Geologija. Geografija“ publikuotų straipsnių atranka pagal raktinius žodžius „žemènauda“, „žemènaudos kaita“. Žurnalo „Geografijos metraštis“ nagrinèti 1958-2017 m. išleisti numeriai, „Geologijos. Geografijos" - 1955-2018 m. (1962-1978 m. žurnalas vadinosi „Geografija ir Geologija“, 19802014 m. - „Geografija“). Tyrimo tematika apžvelgti 1976-2014 m. žurnalo "Geologija“ straipsniai. Vykdant mokslinių straipsnių atranką, i tyrimų apimtis pateko ir dalis kituose leidiniuose, pavyzdžiui, „Geographia Lituanica“, „Baltic surveying“, „Rural development“, „Land use policy“, „Vandens ūkio inžinerija“, „Žemès ūkio mokslai“ ir kt., skelbti Lietuvos autorių straipsniai žeménaudos tematika ar straipsniai, kuriuose užsienio autoriai nagrinejja Lietuvos bei artimų teritorijų žeménaudos kaitą. Analizuoti ịvairaus rango teritorijų kraštovaizdžio, ar siauriau - žeménaudos, struktūros kaitai skirti straipsniai. Itrauktos ir melioracijos problematiką aptariančios publikacijos, jei kartu nagrinejjama melioracijos ịtaka žeménaudos struktūrai. Iš viso atrinktas 161 Lietuvos tyrejjų parengtas straipsnis bei leidinys kraštovaizdžio ir žeménaudos kaitos tematikomis, taip pat 13 užsienio tyrejų straipsnių bendram užsienio tyrimų pobūdžiui nustatyti.

Prie žemėnaudos struktūros tyrimų prisideda ir geografijos, žemès ūkio ir kitų sričių studentų baigiamieji darbai. Daug tokių darbų rengiama Vytauto Didžiojo universiteto Žemès ūkio akademijos (buv. Aleksandro Stulginskio universiteto) Žemètvarkos katedroje, taip pat VU Geomoksluc instituto Geografijos ir kraštotvarkos katedroje (GKK). Autoriai pasinaudojo savo pagrindinès darbovietès, VU GKK, archyve saugomų darbų medžiaga ir ją apžvelgè. Nuo 1968 iki 2016 m. VU geografinių studijų programų absolventų parengta 60 baigiamųjų darbų, susijusių su kraštovaizdžio ir žemėnaudos kaitos tematikomis. Išsamesnei analizei buvo atrinkta 20 darbų, tiesiogiai pristatančių žeménaudos kaitos procesus ir jų dèsningumus. Likusieji darbai ittraukti ị bendrą statistinę analizę.

Analizuojant žemènaudos / žemès dangos tyrimų darbus buvo atsižvelgta ị jų turinị ir parengimo datą, jie suskirstyti pagal laiką ir žemènaudos tyrimų tematikas.

\section{DARBO REZULTATAI ŽEMĖNAUDOS STRUKTŪROS KAITOS TYRIMAI LIETUVOS TYRĖJ̨ DARBUOSE}

\section{Žemėnaudos struktūros kaita, jos prognozès ir formavimas moksliniuose straipsniuose}

Lietuvos kraštovaizdžio transformacija vyko netolygiai, kokybiniais šuoliais, atitinkančiais svarbius politinius, socialinius, ekonominius pokyčius, pertvarkas, dariusias ittaką kraštovaizdžiui (Milius, 1979; Ribokas, Milius, 2007). Dèl minètų priežasčiu suaktyvejjo žemėnaudos kaita, paskatino atsirasti žemėnaudos struktūrą ir jos pokyčius, jų priežastis ir pasekmes analizuojančius mokslinius tiriamuosius darbus. Atsižvelgiant i pagrindinius politinius įvykius - didžiosios sovietinès melioracinès pertvarkos pradžią 1966 m., Lietuvos Nepriklausomybès atgavimą, įstojimą $\mathfrak{i}$ Europos Sąjungą, - kurie istoriškai buvo stipriai susiję su vykstančiomis žemès reformomis ar kitomis - ekonominėmis, socialinėmis - itakomis, siūlome žeménaudos kaitos darbų chronologinę sklaidą skirstyti ị kelis etapus (1 pav.). Pagal turinio pobūdi skiriamos šios publikuotų mokslinių darbų žemènaudos tematika dimensijos: 1) teoriniai-prognoziniai; 2) metodologiniai; 3) politikos formavimo ir taikymo; 4) aprašomieji straipsniai. Pastarieji vyrauja, todèl išskirti keli šių daugiau inventorinio pobūdžio darbų tyrimų lygmenys: lokalusis (vietovès, miesto, seniūnijos), regioninis (rajono, apskrities, istorinio ar pan. regiono) ir nacionalinis. Apibendrinančioje schemoje skirta vietos ir tarptautiniam lygmeniui - $\mathfrak{i}$ šią kategoriją pateko darbas, nagrinejantis Nemuno deltos žemėnaudos kaitą ir apimantis ne tik Lietuvos, bet ir Rusijos teritoriją (Verkulevičiūtè-Kriukienè ir kt., 2018); taip pat lyginamasis darbas žemès naudojimo tendencijoms nusakyti Europos Sąjungoje ir Lietuvoje (Kuncaité, 2003). Tai vieni iš nedaugelio straipsnių, kurie parengti išimtinai Lietuvos autorių, tačiau neapsiribojantys tik savo šalies administracinių ribų teritorija. Pagal 


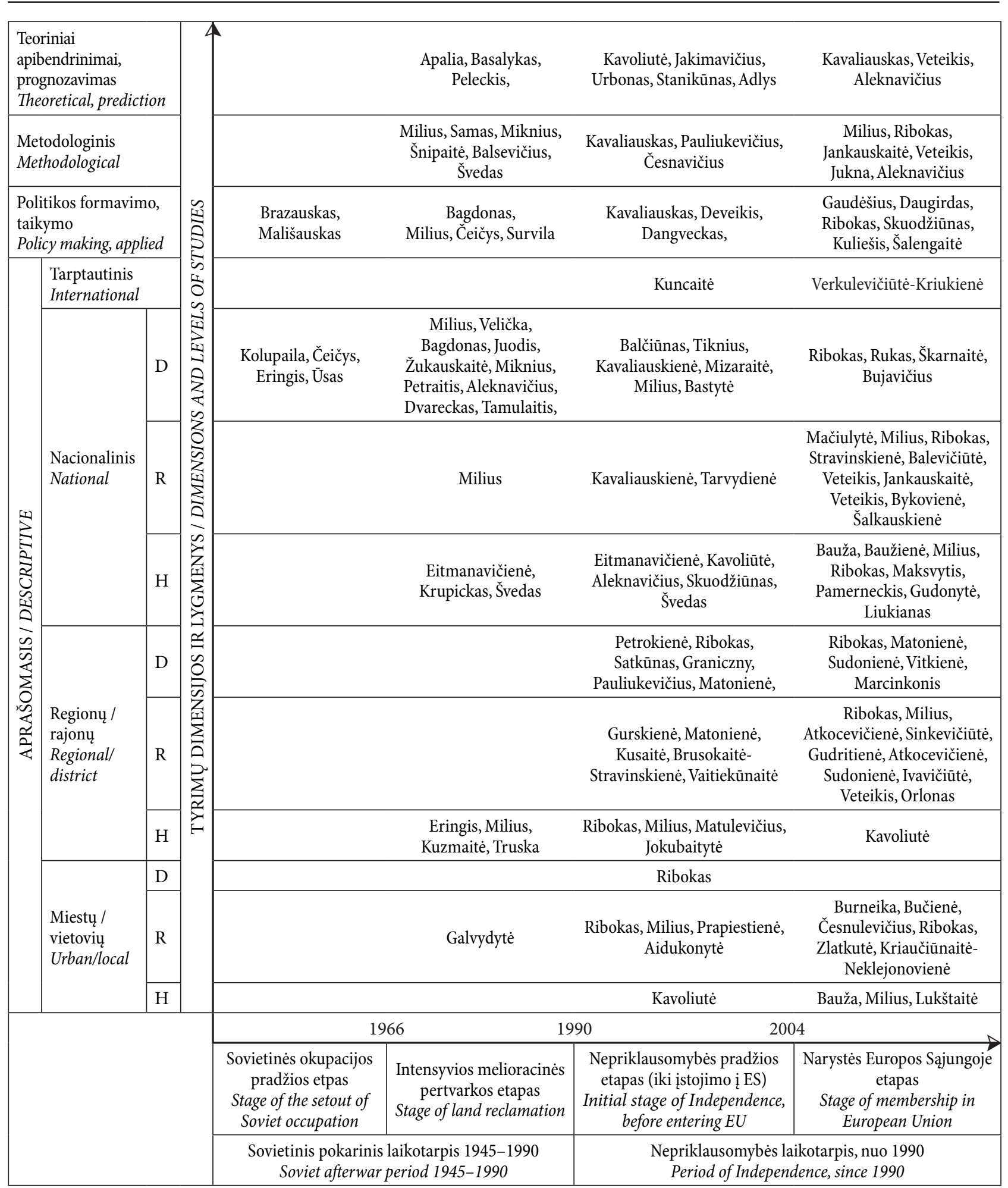

1 pav. Lietuvos tyrëjai ir jų vykdyti bei spaudoje paskelbti arba oficialiose ataskaitose pateikti žemėnaudos struktūros kaitą, jos prognozes, formavimą, tyrimų metodologiją nagrinëjantys darbai: klasifikuota chronologiškai, taip pat pagal tyrimų dimensiją ir teritorinị lygmenį. Esant vienam ar dviem darbo autoriams, pateiktos visos pavardès, jei trys ir daugiau - tik pirmoji

Fig. 1. Lithuanian scientists and specialists according to their published research or official reports on landuse/land cover changes, formation, research methodology - classified chronologically, also by research dimension and territorial level. In case of one to two authors, all the surnames are given, if three and more - only the first

Santrumpos: D - tyrimai, orientuoti ị esamą žemès naudmenų struktūrą, būklę, reiškinius, susijusius su jų dabartine kaita; $\mathrm{R}$ - retrospektyviniai tyrimai, apimantys sąlyginai nedidelị praeities laikotarpi (10-20 metų); $\mathrm{H}$ - istoriniai žemès naudmenų kaitos tyrimai. Abbreviations: $D$ - researches oriented to the existing structure, condition, phenomena of relation to their current change; $R$ - retrospective researches covering a relatively small period of the past $10-20$ years; $H$ - historical land use research. 
chronologinę aprèptį aprašomieji nacionalinio ir žemesnio rango darbai dar skirstyti į: 1) orientuotus ị esamą žemès naudmenų struktūrą, būklę, reiškinius, susijusius su jų dabartine kaita; 2) retrospektyvinius tyrimus, apimančius sąlyginai nedideli praeities laikotarpi (10-20 metų); 3) istorinius žemès naudmenų kaitos tyrimus (1 pav.).

Išsamiai pristatomos skirtingiems laikmečiams būdingos darbų kryptys, taip pat lygmenys.

\section{Sovietinis pokarinis laikotarpis (1945-1990 m.)}

Nors šis laikotarpis, palyginti su Europa, Lietuvoje pasižymejjo gana vientisu žemètvarkos režimu - kolektyvizacija (Jepsen ir kt., 2015), gali būti skirstomas $\mathfrak{i}$ du etapus: a) sovietinès okupacijos pradžios (iki 1966 m.); pasižymejjo ryškesniais įvykiais politineje ir socialineje sferoje, taip pat geografinių darbų žeménaudos tematika stoka, ir b) melioracinès pertvarkos (nuo 1966 m.); prasidejo Lietuvos žemènaudų struktūros tiesioginiai dramatiški pokyčiai, pagausejo geografinių darbų žemėnaudos tematika.

Pirmaisiais sovietmečio pradžios dešimtmečiais kryptingų geografinių darbų žeménaudos tematika yra palyginti mažai. Pasirode tik pavieniai straipsniai, susiję su žemès naudmenų kiekybiniais rodikliais, ekonominiu vertinimu (Brazauskas, 1958; Mališauskas, 1961), nagrinèta melioracijos tema, netiesiogiai tik užsiminta apie žemėnaudą (Kolupaila, 1954; Čeičys, 1957; Ūsas, 1966).

Žemenaudos kaitos tyrimai suaktyvejo nuo 7-ojo dešimtmečio, ypač nagrinèjantys $\mathrm{XX}$ a. agrarinèse vietovėse žemės reformų nulemtą žeménaudos kaitą. Nors darbuose minimas nuoseklių istorinių tyrimų (Eitmanavičienè, 1981) ir tuometinis statistinių šaltinių trūkumas, (Milius, 2009), jau pasirodè straipsnių apie žeménaudos struktūros kaitą nuo XX a. pradžios (Samas, 1972). Suprasta praeityje vykdytų žemètvarkos reformų pažinimo svarba vietovès žemėnaudos kaitos istoriniams tyrimams, jų ittaka dabartinei žeménaudos struktūrai (Bagdonas, 1976). Visos Lietuvos tolimos praeities (XVI, XIX a.) kraštovaizdžio, ypač žemènaudos, kaitą, tuometinę žmogaus darytą ịtaką kraštovaizdžiui tyrè N. Eitmanavičienè (1976, 1984). Apibūdinti XVI a. Vidurio Lietuvos žemėvaldos bruožai (Eringis, Milius, 1976) ir bažnytinè žemėvalda Žemaitijoje XV-XVIII a. (Kuzmaité, 1979a; 1979b). Taip pat atliktas žemévaldos ir feodalų klasès struktūros Lietuvoje XVIII a. pab. tiriamasis darbas (Truska, 1985).

Sovietinio laikotarpio melioracinès pertvarkos laikotarpiu aktualūs tapo darbai, nagrinèjantys Lietuvos žeménaudą ir jos kaitą atsižvelgiant $\mathfrak{i}$ skirtingus kraštovaizdžio tipus, ūkines pertvarkas, apskritai gilinamasi $\mathfrak{i}$ agrarinio kraštovaizdžio tyrimo metodologines problemas (Milius, 1974, 1976, 1979, 1983, 1984a, 1984b). Šias tyrimų kryptis nagrinejjo ir kiti autoriai (Galvydyte, 1973; Bagdonas, 1976; Apalia, 1982). Nemaža dalis darbų skirta intensyviai vykdomai melioracijai (Šnipaité, 1968; Velička, 1972; Tamulaitis, 1985; Tiknius, 1988; Peleckis, 1989).

Idomu tai, kad aptariamam laikotarpiui nebūdingi miestų žemėnaudą nagrinejjantys darbai.

\section{Nepriklausomybès laikotarpis (nuo 1990 m.)}

Šiame laikotarpyje pažymėtina chronologinè riba - Lietuvos Respublikos $2004 \mathrm{~m}$. ịstojimas $\mathfrak{i}$ Europos Sąjungą (ES), ji vieną nuo kito atskiria $\mathrm{du}$ etapus. Pirmasis - Nepriklausomybès pradžios - ūmaus žemès grąžinimo, sovietinių ūkių naikinimo, akcinių bendrovių kūrimo laikotarpis, M. R. Jepseno ir kt. (2015) ìvardytas kaip ūkinès veiklos intensyvejimo etapas. Šiuo laiku F. Kavoliutès (1993, 1994) ir N. Eitmanavičienès (1994) darbai apima visos šalies kraštovaizdžio struktūrinių elementų, žemènaudos kaitą ir raidą, tačiau daug daugiau atsiranda straipsnių, nagrinejjančių atskirų regionų, vietovių, miestų žeménaudos struktūrą, jos artimos ir tolimos praeities kaitą.

Naujomis ekonominèmis sąlygomis pagyvejusi urbanizacija paskatino gyvenviečių žemėveiksliu (Ribokas, Aidukonytè, 1998; Ribokas, 1999) ar konkrečių miesto struktūros dalių - miesto žaliųjų plotų (Prapiestienè, 2003) ar kaimų (Kavoliutė, 1996) - tyrimus. Dèl politinių, ekonominių ir socialinių sąlygų kaitos pasikeitusi situacija agrarinèse teritorijose paskatino daugiau tyrinèti žemènaudos ypatybes sudètingu ūkinių sąlygų teritorijose (Ribokas, Milius, 2001), konkrečiai aktyvaus karsto zonoje (Petrokienè, Ribokas, 1996), atkreipti démesị ì nederlingas (Stanikūnas, 1997) ir apleistas žemes, renatūralizacijos procesą (Kavoliutè, 1993; Agrarinès..., 2000), kelti senosios žemènaudos tyrimo bei išsaugojimo problemas (Kavoliute, 1995).

Šiuo laikotarpiu P. Aleknavičiaus ir V. Skuodžiūno parengtas apžvalginis darbas „Žemès 
tvarkymo darbai Lietuvoje: nuo seniausių laiku iki 1990 metų" susistemino iki 1990 m. vykdytą žemès tvarkymo politikos istoriją (Aleknavičius, Skuodžiūnas, 1996). Nuo 1990 m. parengta ir daugiau istorinès žeménaudos tyrimų (Eitmanavičienè, 1994; Kavoliūtè, 1994; Matulevičius 1997; Milius, 1997).

Antrasis ir naujausias nepriklausomybès laikotarpio narystès ES etapas pasižymèjo žemènaudos duomenų gausa, tobulesnèmis kartografavimo technologijomis ir tyrejuc aktyvumu. Atsirado darbų, kuriuose pradètas vertinti ir naujosios teisinès konjunktūros poveikis žemėnaudos pokyčiams, ES paramos ittaka žemès naudojimo intensyvumui ir kryptingumui (Stravinskiene ir kt., 2011; 2015), be to, naujai žvelgiama ir į socialinį aspektą - vertinama ne tik ES paramos itaka, bet ir vykdomos analizès, ūkininkų apklausos, padedančios numatyti netolimos ateities žemėnaudos ypatumus (Ribokas, Milius, 2001; 2008; Mačiulytė, 2006; Ribokas, Rukas, 2006; Ribokas, Zlatkute, 2009; Kuliešis, Šalengaitè, 2011; Ribokas, 2012). Šiuo laikotarpiu atlikta ypač daug darbų, labai ịvairi jų tematika. Atsirando tiek bendrų, tiek konkrečias žemènaudos rūšis nagrinèjančių tyrimų, jie apèmè visą šalies teritoriją (Ribokas ir kt., 2007; Bauža, Baužienè, 2008; Milius ir kt., 2008; Gauděšius, 2011; Bykovienè ir kt. 2014; Aleknavičius, 2017). Kita vertus, palyginti su kitais laikotarpiais, atlikta daugiau ir lokalinių bei regioninių tyrimų. Nagrinètos ne tik miestų (Bauža, 2005; Burneika, 2008), atskirų rajonų savivaldybių (Ribokas, Zlatkutè, 2009; Orlonas, Veteikis, 2016) ar tik seniūnijų (Česnulevičius ir kt., 2005; Bučienè ir kt., 2017) vietovès, bet ir specifinès, savitų bruožų turinčios teritorijos, pavyzdžiui, dirvonai (Milius, Ribokas, 2008), saugomos (Jokubaitytè, 2003; Kavoliutè ir kt., 2014) ar etaloninès teritorijos, kuriose atliktų tyrimų rezultatai naudojami bendroms tendencijoms nusakyti (Kraštovaizdžio ..., 2008; 2015). Pažymètinas svarus žemès ūkio mokslų srities tyrëjų inašas. Jų darbuose nagrinejjama ne tiek teritorinè žemès naudmenų pokyčių išraiška, kiek veiksniai, lemiantys žeménaudos, agrarinio kraštovaizdžio kaitą: natūralios gamtinès sąlygos teritorijoje, žemès ūkio žemių naudojimo politika (Atkocevičienè, 2010), parama žemès ūkiui (Stravinskienè, 2015), žemètvarkos planavimas (Atkocevičienè, 2011) ir kt. Vertinama visuma sudetinių dalių, darančių įtaką ne tik žeménaudos kaitai, bet ir žemès ūkio tradicijoms, ūkininkavmo intesyvimui (Atkocevičienè, 2010; Stravinskienė, 2015), gyventojų skaičiaus kaitai agrarinèse teritorijose (Sinkevičiūtè ir kt., 2011).

Tyrëjai pastebi vykstančius pokyčius specifinèse teritorijose, stiprejjančias tendencijas, aktualius reiškinius. Tyrimų objektu tampa sodų bendrijų teritorijos (Kriaučiūnaitè-Neklejonovienè ir kt., 2015), ekologinių ūkių teritorijos (Stravinskienè ir kt., 2011). Šiu teritorijų plètra skatina perprasti jų augimą lèmusias priežastis, tolimesnio vystymosi tendencijas. Aktualūs išlieka tyrimai, kuriuose nagrinejjamos apleistos (Kuliešis, Šalengaitè, 2010; Ribokas, 2011), pažeistos (Ivavičiūtè, 2017), neproduktyvios žemès (Šalkauskienè ir kt., 2017), kur atkreipiamas dèmesys ị renatūralizacijos procesus (Balevičiūtè, Veteikis, 2012).

Per visą apžvelgtą gana ilgą žemènaudos kaitos tyrimų laikotarpi (1958-2019 m.) darbuose galima įžvelgti tam tikrų Lietuvai būdingų probleminių sričių, metodologinių ir sampratos, traktavimo ypatumų. Visų laikotarpių tyrimuose taikomos panašios metodologinès schemos: remiamasi statistine informacija, atliekama istorinio konteksto analizé, pateikiama schematiné, kartografinè informacija. Daugelio tyrimų išvadose siekiama atskleisti žemènaudos kaitą lèmusias priežastis, tendencijas ir prognozes, kai kurie autoriai pamini, kad atlikdami tyrimus susidūre su techninemis kliūtimis (Milius, 1954a; Česnavičius, 1999; Aleknavičius, 2005). Ne vienas tyrẻjas ivardija sąvokų kaitos (Prapiestienè, 2003; Milius, Ribokas, 2008), žemènaudos tipologijos kaitos (Milius, 1974; Bauža, 2005; Milius, Ribokas, 2008) bei kartografavimo problemas (Aleknavičius, 2004), pateikia ir rekomendacijas, siūlymus problemų, susijusių su sąvokų ar žeménaudos tipologijos, klasifikacijos kaita, sprendimui (Milius, 1974; 1984). Skirtingu laiku aktualūs darbai pabrèžè, kad būtina sunorminti žemènaudos rūšių tipologiją ir terminiją (Milius, Ribokas, 2004), nuolatos atnaujinti žemènaudos pirminius - kartografinius - šaltinius (Bykovienė ir kt., 2014), buvo kuriama kraštovaizdžio stebèsenos metodologija, iš esmès paremta žemėnaudos kaitos fiksavimu (Jankauskaitè, Veteikis, 2010). Siūlomi konceptualūs sprendimai žeménaudos struktūrą formuojančiai žemètvarkos sistemai, siekiant subalansuoto, kokybiško kraštovaizdžio formavimo (Kavaliauskas, 1997). 
Žemėnaudos struktūros kaitai skirti darbai (analizuotas 161 darbas) per 1954-2018 m. laiko atžvilgiu pasiskirsto netolygiai - stebima atliekamų tyrimų skaičiaus kaita, jų pagausèjimas arba sumažejimas (2 pav.).

Vertinant tyrejuc darbų kieki laikotarpiais ar jų skaičių atskirai kiekvienais metais matyti, kad žemènaudos kaitos tyrimų skaičius ir apskritai dèmesys žemènaudos pokyčiams pastaraisiais dešimtmečiais auga. Jei nuo 1954 iki 1983 m. yra laikotarpių, kai nebuvo parengta nè vieno straipsnio žeménaudos kaitos tema, tai nuo 1983 m. kiekvienais metais atliekama bent po vieną ar daugiau tyrimų. Daugiausia straipsnių (8) parengta 2004 metais. Nuo $2000 \mathrm{~m}$. demesys žeménaudos struktūroms yra sumažèjęs, mokslinių darbų parengta mažiau.

\section{Žemėnaudos kaitos tyrimai Vilniaus} universiteto studentu baigiamuosiuose darbuose Studentų baigiamieji darbai atspindi jų mokslinių vadovų - subrendusių tyrejuc - mokslinius interesus, todèl yra iddomus mokslotyrinès informa- cijos šaltinis. Tarp atrinktų žemėnaudos / žemės dangos tematikai skirtu studentu darbu vyravo tiek agrarinèse, tiek urbanizuotose teritorijose vykstančių procesų (ir renatūralizacijos) analizè. Baigiamieji darbai remiasi keliomis pagrindinèmis metodikomis - istorine analize, statistiniu duomenų apibendrinimu ir kartografine analize, dažniausiai tai ortofoto vaizdų vektorizavimas arba turimų žemès dangos duomenų GIS analizè.

Žeménaudos kaitos tematikos darbai, parengti iki Nepriklausomybės atgavimo, nors ir neišsiskiria gausa, tačiau vertinant iš šiandienos perspektyvos yra tematiškai ịvairūs ir vienetiniai, kadangi vèlesniais laikotarpiais panašūs darbai nebebuvo rengiami. Dalis iki 1990 m. parengtų darbų apima kraštovaizdžio, žemès naudmenų kaitos sritis, gilinasi $\mathfrak{i}$ techninę, gamybinę tyrimo perspektyvą ir yra labiau orientuoti ì praktini pritaikymą nei i mokslini procesų išaiškinimą. Parengti baigiamieji darbai, kurie tiria konkrečių kolūkinių vienetų landšaftus ir galimą jų ūkinị panaudojimą, kituose pateikiama melioruojamu ir numelioruotų žemių blokdiagrama ar nagrinèjamas ūkių

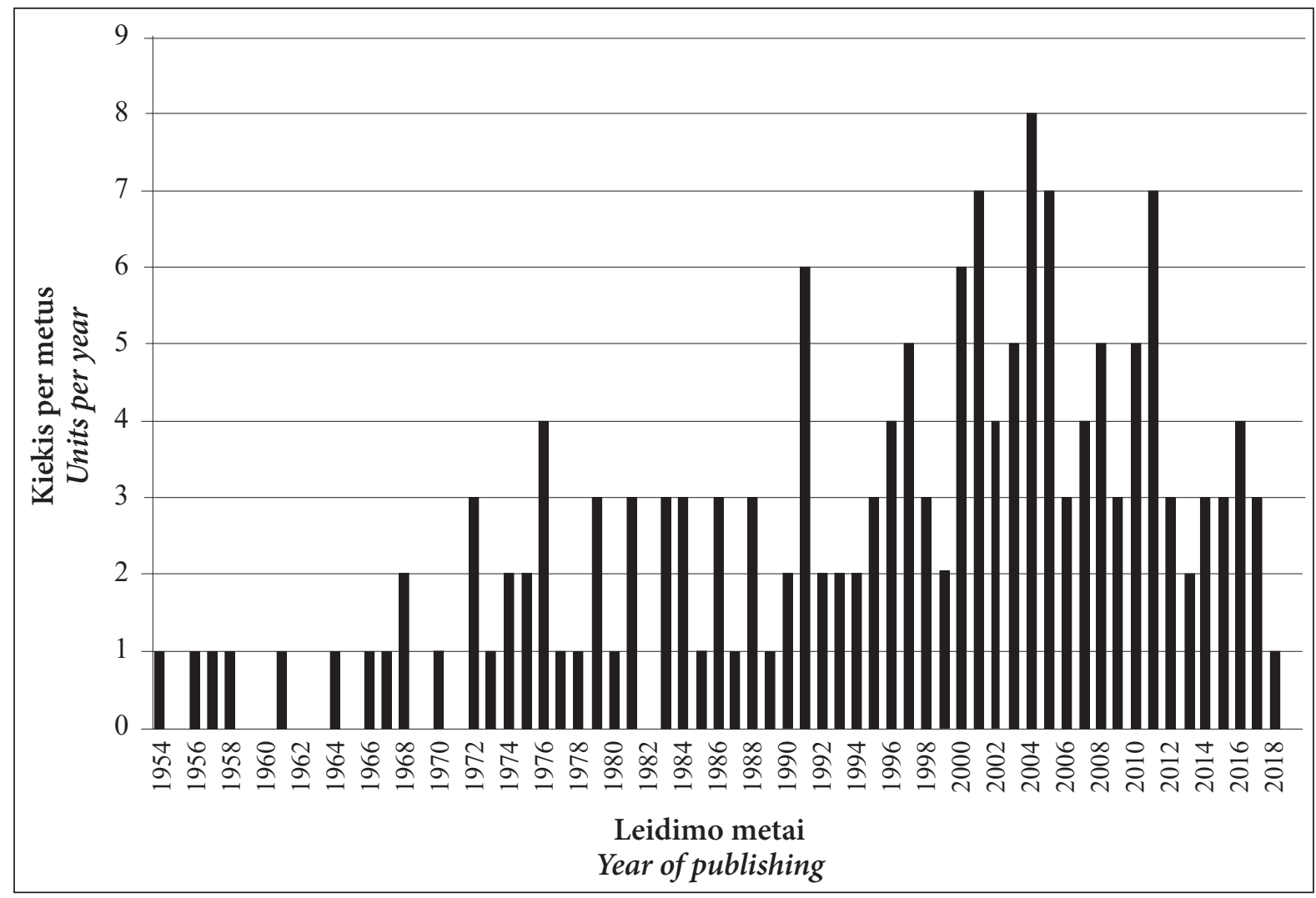

2 pav. Lietuvos tyrëjų publikuotų darbų žemėnaudos struktūros kaitos tematika skaičius per metus 1954$2018 \mathrm{~m}$.

Fig. 2. Lithuanian authors' published research on land use change, units per year during 1954-2018 
žemès balansas. 1983 m. parengęs baigiamąji darbą tema „Žemès ūkio naudmenų dinamika kalvotose moreninèse aukštumose (Utenos administraciniame rajone)“ G. Ribokas ir vèliau domejjosi žeménaudos kaita, paskelbè ne vieną mokslinị straipsni žemènaudos tematika. Tačiau didžiausias žeménaudos tematikos baigiamųjų darbų kiekybinis šuolis stebimas nuo 2000 metų. Ypač daug darbų parengta nagrinejjant regionų, vietovių ar miestų kraštovaizdžio, žemenaudos ypatumus. Tokių studentų darbų yra daugiau, negu paskelbta mokslineje spaudoje.

Regionai, $\mathfrak{t}$ kuriuos studentų darbuose sutelkiamas dèmesys, būna pasirenkami arba administracinio skirstymo pagrindu - tai rajonai, savivaldybių teritorijos, apskritys ir pan. (Rukas 2006; Džermeika, 2008; Gulbinas, 2011; Braukaité, 2013; Viltrakis 2013; Šakinytè, 2014; Piskunovas, 2015 ir kt.), arba hidrografinio tinklo pagrindu - tai baseinai arba jų dalys (Saiminikai- tè, 2011; Totorytè, 2014; Janušaitè, 2016 ir kt.). Didžioji dalis žeménaudos kaitos tematika VU baigiamųjų darbų nagrinèja agrarinị kraštovaizdị. Kaip ir mokslinių straipsnių tyrimuose, taip ir baigiamuosiuose studijų darbuose akcentuojami pagrindiniai istorijos lūžio taškai, kai žemènauda patyrè didžiausias transformacijas. Darbuose, parengtuose po 2004 m., t. y. po įstojimo it Europos Sąjungą, be politinių, istorinių aplinkybių, vertinama ir Europos Sajungos parama, jos reikšmé agrarinès žemėnaudos, apgyvendinimo pokyčiams, atkreipiamas dèmesys į Europos Sajungos paramos ir politikos daromą ar numanomą ateityje ittaką žeménaudos kaitos procesams (Džermeika, 2008; Šakinytė, 2014; Šiurpyte, 2015).

VU studentų baigiamųjų darbų tyrimai šalies teritoriją apima netolygiai (3 pav.).

$\mathrm{Su}$ tam tikra rezervacija (dèl ìvairios darbu mokslinès kokybès) galima priimti, kad studentu baigiamųjų darbų indèlis ì bendrą žemènaudos

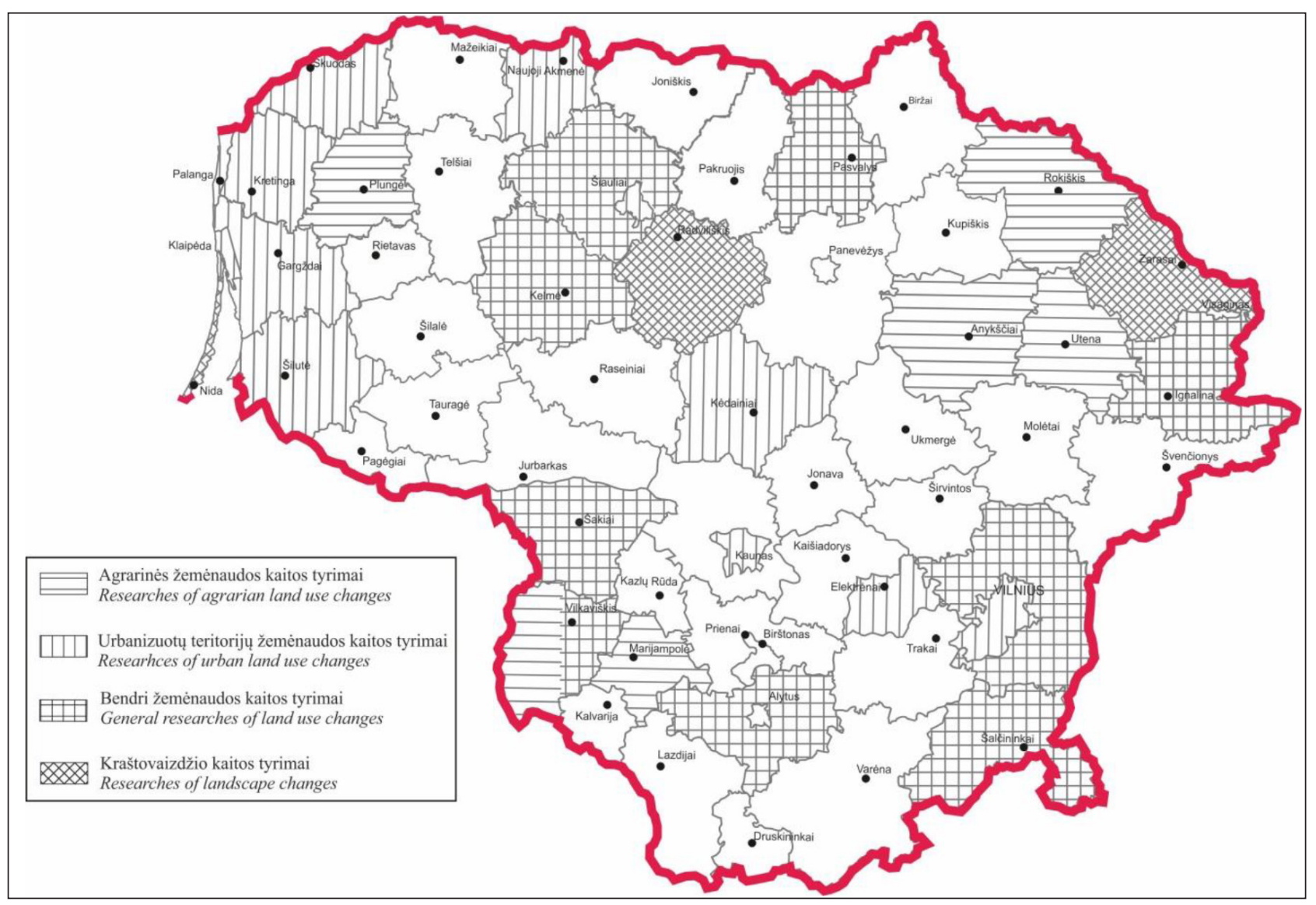

3 pav. Vilniaus universiteto geografijos krypčių studentų baigiamųjų darbų (bakalauro ir magistro), skirtų vietos lygmens žemėnaudos kaitai, teritorinis pasiskirstymas

Fig. 3. Territorial cover of master and bachelor theses of Vilnius University geography students devoted to land use change on local level 
srities pažinimą irgi reikšmingas, nes atskirų nedidelių teritorijų tyrimų rezultatai gali būti naudojami platesnio masto apibendrinimuose (tiesa, kol kas tai nebuvo daryta).

\section{LIETUVOS IR KAIMYNINIŲ TERITORIJŲ ŽEMĖNAUDOS STRUKTŪROS KAITA UŽSIENIO TYRĖJŲ DARBUOSE}

Be faktinių žemėnaudos kaitos analizių, užsienio autorių tyrimai nagrinèja žemėnaudos kaitą lemiančius veiksnius, atsižvelgdami $\mathfrak{i}$ istorinị kontekstą, teisinę bazę, siūlo naujas metodologijas, agrarinių teritorijų klasifikacijas, parankesnes žemès politikos formavimui ir kt., darbai yra ne lokalaus pobūdžio, o apima visą Europos subkontinentą (Hartvigsen, 2014; Jepsen ir kt., 2015; Banski, 2016; Plieninger ir kt., 2016).

Daugumoje užsienio autorių straipsnių (apimančių ir Lietuvos teritoriją) žeménaudos kaita nèra pagrindinis tyrimo objektas, o tik iliustracinè medžiaga nagrinèjamiems politiniams ịvykiams, žemès reformoms pagrịsti (Bezemer ir kt., 2006; Gaudėšius, 2011). Lietuva kai kuriuose užsienio autorių darbuose ittraukiama į stambesnių regionų (dažniausiai Rytų Europos) žemėnaudos kaitos analizę istorinių-politinių ìvykių kontekste, pavyzdžiui, po Sovietų Sąungos žlugimo (Prishchepov ir kt., 2012; Gutmans, Radeloff, 2017).

Lietuvos žemènaudos struktūros kaita Europos kontekste nagrinèta ne viename europinio masto tyrime. Analizuojant tokius procesus kaip visos Europos urbanizacijos pletra (Antrop, 2004) ar miškų praradimas (Kaplan ir kt., 2009) nuo priešistorinių laikų, Lietuvos teritorija patenka $\mathfrak{i}$ tyrimo erdvę, tačiau atskiro dèmesio nesulaukia. Išskirtini atvejai, kai Lietuvą reikia įtraukti ị statistinę analizę kaip atskirą regioną, pavyzdžiui, rekonstruojant paskutinio šimtmečio Europos žemès dangos evoliuciją (Fuchs ir kt., 2015) arba kai mūsų šalyje pastebimas žemėnaudos kaitos karštasis taškas, pavyzdžiui, 2000 ir 2012 m. Šiaurès rytineje Lenkijoje ir Lietuvoje buvo stebimas apleistų žemių plotų spartus didejjimas, palyginti su visa Europa (Kuemmerle ir kt., 2016).

Užsienio moksliniuose darbuose bendraautoriais tapę Lietuvos ir užsienio tyrẻjai nagrineja mūsų šalies ir kaimyninių teritorijų žemètvarkos režimus (Jepsen ir kt., 2015), žeménaudos kaitą, pavyzdžiui, Lietuvos-Lenkijos (Senetra ir kt.,
2013) arba Lietuvos-Baltarusijos (Vitkutè, 2017) pasienio ruožus.

Pastarojo laikmečio kaimyninių šalių darbų pavyzdžiai rodo, kad žemėnaudos tyrimų problematika yra panaši kaip ir Lietuvoje, pavyzdžiui, apleistos, pažeistos žemès Latvijoje (Abolina ir kt., 2015; Arika ir kt., 2017) arba žemès ūkio paskirties žemių plotų kaita Lenkijoje (Cegielska ir kt., 2018).

\section{APIBENDRINIMAS}

Apibendrinus išanalizuotus darbus pagal tyrimu kryptis paaiškejo, kad Lietuvoje daugiausia atlikta žeménaudos ir kraštovaizdžio kaitos bei agrarinès žeménaudos, kiek mažiau - urbanizuotų teritorijų, kaitos tyrimų. Dar yra upių slènių ir baseinų žemėnaudos kaitos tyrimų, juos daugiausia atliko studentai. Išryškejo mokslinių straipsnių ir studentų baigiamųjų darbų pasiskirstymas pagal teritorinius lygmenis. Didžioji dalis mokslinių straipsnių orientuoti $\mathfrak{i}$ regioninius, nacionalinius tyrimus, o baigiamieji studijų darbai - ị mažas teritorijas.

Daugiausia darbų yra analitinio, inventorizacinio pobūdžio, nagrinèjančių žemènaudos kaitą ivairiausio lygmens teritorijose, dauguma iš dalies apima ir priežasčiu paiešką. Palyginti nedidelè dalis darbų yra skirti teoriniams apibendrinimams, prognozavimui ar yra metodologinès krypties. Pagal tyrimo objektą daugiausia parengta darbų, analizuojančių agrarinès žemènaudos kaitos procesus. Galima teigti, kad darbų tematika labiausiai priklauso nuo tuo metu vykdomos žemès valdymo formos, socialinių ir ekonominiu veiksnių, kitų aktualijų (1 pav.).

Matyti, kad pastaraisiais dešimtmečiais žemènaudos tyrimų ypač padaugèjo. Šią temą nagrinèja tiek mokslininkai, tiek studentai baigiamuosiuose darbuose. Daugumos darbų kryptys yra panašios ir viena kitą papildančios. Lietuvos mastu situaciją nagrinejjantys darbai turi panašią struktūrą ir netgi tikslą. Darbuose pastebima ir vyraujanti žeménaudos kaitos tarpsnių klasifikacija. Vieningai pripažįstami Lietuvos istorijos momentai, autorių darbuose ịvardijami kaip lūžio taškai, lèmę ypač ryškią žeménaudos transformaciją.

Kita vertus, bendrąsias šalies tendencijas nagrinejjančiuose darbuose pasigendama tarptautinès dimensijos, neịvertinami kaimyninèse 
valstybėse vykstantys procesai, nèra palyginamosios analizès.

Lokaliniai žeménaudos kaitos tyrimai nèra koordinuoti, jų visuma turi padriką pobūdị. Kai kuriuose administraciniuose vienetuose vietos lygmens žeménaudos kaitos tyrimai atlikti ne vienoje vietoje ar net ne po vieną kartą, o kituose šių tyrimų iš viso neatlikta. Kita vertus, tobulèjant kartografavimo technologijoms, greitejant erdvinès informacijos skaitmeninimo (aerofoto vaizdų dešifravimo) procedūroms tampa įmanomas visos šalies detalus (pvz., mastelis $1: 10$ 000) žemėnaudų kartografavimas. Dabar pasitelkiamas aerofotografavimas, sekama žemès paviršiaus situacija ir nuolatos atnaujinama valstybinio georeferencinio pagrindo duomenų bazè, kuri, nors ir nèra pakankamai išsami žemès naudmenų / žemès dangos ịvairovès požiūriu, be to, yra palyginti jauna (sudarinèjama tik nuo 2008 m.), ateityje galès būti panaudojama detalaus ir visos šalies mastelio analizei.

Verta pažymèti, kad Lietuvos žemėnaudos kaitos tyrimai iš esmés atspindi Europoje atliktų žeménaudos kaitos tyrimų tendencijas (Plieninger ir kt., 2016) - didžioji dalis tyrimų atliekami vertinant pokyčius nedideliuose regionuose ir neilgos trukmès (kelių dešimtmečių), nepakankamas dėmesys skiriamas miškingų vietovių žeménaudos tyrimams, o koncentruojamasi it agrarinị kraštovaizdị. Lietuvos tyrèjų publikacijose, VU studentų baigiamuosiuose darbuose išskirtos žemènaudos kaitos priežastys iš esmès atspindi globalias tendencijas ir priežastis, dažniausiai minimos istorinès, politinès, gamtinès arba konkrečiose vietovèse - žemès naudojimo intensyvumo kaita, žemių našumo praradimas, dirbamų žemių apleidimas. Atsižvelgiant i Europos žemènaudos tyrimų problematiką, Lietuvoje taip pat būtų galima rekomenduoti ịtraukti $\mathfrak{i}$ tyrimus mažai ištirtus kraštovaizdžių tipus ir vietoves, identifikuoti svarbiausius kraštovaizdžio kaitos veiksnius, taikyti patikimesnius kiekybinès kraštovaizdžio kaitos analizès metodus, vykdyti tyrimus, apimančius ilgesnius istorinius laikotarpius ir tarpvalstybinius regionus, atsižvelgti $\mathfrak{i}$ subtilius ir naujus kraštovaizdžio procesus. Be to, pravartu tyrinèti stabilias, mažai besikeičiančias žemènaudos struktūras, padèsiančias nustatyti veiksnius, atsparius išorès poveikiui. Pritariant čia aprašytam poreikiui užpildyti kultūrinio kraštovaizdžio struktū- ros pažinimo spragas, verta akcentuoti, kad, be operatyviu artimiausio laikotarpio ir retrospektyvių netolimos praeities žemès naudmenų tyrimų, mūsų kraštovaizdžio pažinimui, jo atminties ir paveldo išsaugojimui svarbūs ir tolimosios praeities istoriniai kraštovaizdžio tyrimai, kurių mūsų šalyje labai trūksta. Turi būti semiamasi patirties iš analogiškų užsienio tyrimų, kuriamos naujos arba tobulinamos esamos metodologijos, pavyzdžiui, senuju žemèlapiu skaitmeninimas ir analizé, taip pat vietovès distanciniai tyrimai ir kiti metodai, skirti senojo mūsų šalies kraštovaizdžio pažinimui, jo struktūrų atpažinimui.

\section{IŠVADOS}

1. Per pastaruosius 60 metų atliktuose Lietuvos tyrejuc darbuose žemėnaudos ir jos kaitos tematika atskleidžiami: visuomenès politinių, socialinių, ekonominių procesų, lūžių ịtakos žemėnaudos kaitai suvokimas, svarbiausi XX ir XXI a. žemėnaudos pokyčiai, susirūpinimas kraštovaizdžio tvarumu ir jo kultūrinio sluoksnio, kuriam priklauso ir žemėnaudos struktūra, išsaugojimu. Darbų nuolatos daugejo, proporcingai įvairesnè tapo tematika.

2. Atlikti žemėnaudos kaitos tyrimai gali būti klasifikuojami pagal įvairius parametrus: mastelị, tyrimų krypti, teritorinę ir chronologinę aprèpti. Pastarųjų dviejų dešimtmečių informacinių technologiju šuolis, palengvinęs žeménaudos struktūros tyrimus iš kosminių ir aerofoto vaizdų, paspartinęs erdvinès geografinès informacijos apdorojimą, padaugèjo žemènaudos tyrimų, orientuotų i žemènaudos kaitos pokyčius, vykusius po Nepriklausomybės atgavimo. Tolimosios praeities ir istoriniai tyrimai užima nedidelę tyrimų dalį, kadangi trūksta ne tik istorinių, ypač kartografinių šaltinių, bet ir metodologinio pagrindo pastarųjų korektiškai analizei.

3. Lokalinių žemėnaudos kaitos tyrimų visumą papildo studentų baigiamieji darbai, tačiau jie nèra koordinuojami, todèl vyrauja didelè chronologinè, geografinè ir tematinè darbų ịvairové. Tyrimų kryptingumą galètų formuoti sukurta metodologija, leidžianti panaudoti šių tyrimų rezultatus kaip etalonus, pavyzdžius šalies žeménaudos situacijai apibendrinti.

4. Atsižvelgiant i̇ Europos tyrejų žemènaudos kaitai skirtus apžvalginius darbus, siūlytina 
i Lietuvos geografinius žemènaudos tyrimus įtraukti mažai ištirtus kraštovaizdžių tipus ir vietoves, identifikuoti svarbiausius kraštovaizdžio kaitos veiksnius, tobulinti kiekybinès kraštovaizdžio kaitos analizès metodus, vykdyti tyrimus, apimančius ilgesnius istorinius laikotarpius ir tarpvalstybinius regionus, ieškoti bei atsižvelgti i nekintančius ir naujus kraštovaizdžio procesus, tyrinèti stabilias, mažai besikeičiančias žemènaudos struktūras, padèsiančias nustatyti veiksnius, atsparius išorès poveikiui.

\section{PADE்KA}

Straipsnio autoriai nuoširdžiai dèkoja VU Geografijos ir kraštotvarkos katedros vyr. specialistui Rimantui Šilagaliui už galimybę pasinaudoti jo surinkta gausia 1940-2009 m. žemètvarkos, žemènaudos, kraštovaizdžio ekonomikos, melioracijos tematikų bibliografijos kartoteka. Tai labai pagreitino straipsnio rengimą ir pagerino jo kokybę.

Gauta 20190409 Priimta 20190503

\section{LITERATŪRA}

1. Agrarinès žemènaudos konversijos pasekmiu prognozé: ataskaita. 2000. Vilnius: Geografijos institutas. $49 \mathrm{p}$.

2. Aleknavičius P. 2004. Žemès naudmenu pokyčiai ir kartografavimo problemos. Žemétvarka ir hidrotechnika. 4: 7-10.

3. Aleknavičius P. 2002. Žemès naudojimas Lietuvoje: problemos bei perspektyvos. Žemetvarka ir hidrotechnika. 2: 35-39.

4. Aleknavičius P. 2017. Veiksniai, darantys ịtaką kultūrinio agrarinio kraštovaizdžio pokyčiams Lietuvoje. Geografija. 38(1): 11-24.

5. Aleknavičius P., Skuodžiūnas V. 1996. Žemès tvarkymo darbai Lietuvoje: nuo seniausiu laiku iki 1990 metu. Lietuvos žemètvarkos ir hidrotechnikos inžinierių sajunga.

6. Antrop M. 2004. Landscape change and the urbanization process in Europe. Landscape and Urban Planning. 67: 9-26.

7. Apalia Dz., Černius J., Kudaba Č. 1982. Pažeistos žemès ir ju rekultivavimas. Geografijos metraštis. 20: 196-204.

8. Arika E., Mazure G. 2017. Problems and solutions for abandonment of utilised agricultural ares in Latvia. International Conference "Economic science for rural development". 44: 307-314.
9. Armonavičius T. 2006. Gyvenamosios statybos teritorine sklaida ir pokyčiai Vilniuje 19952005 metais: bakalauro darbas. Vilnius: VU Geografijos ir kraštotvarkos katedra.

10. Atkocevičienė V., Sudonienè V. 2010. Žemès naudmenų kaitos analizè agroūkinio zonavimo teritorijose. Ekonomika ir vadyba: aktualijos ir perspektyvos. 3(19): 92-102.

11. Atkocevičienè V., Gudritienè D., Sudonienè V. 2011. The analysis on the change of farming lands in the territory of middle Lithuania. Baltic surveying. 11: 25-36.

12. Bagdonas J. 1976. Žemètvarka ir geografinè aplinka Lietuvoje. Geografijos metraštis. 14: 111-122.

13. Balevičiūtè A. 2012. Renatūralizacijos pokyčiai Lietuvos kraštovaizdyje 1995-2010 m.: bakalauro darbas. Vilnius: VU Geografijos ir kraštotvarkos katedra.

14. Balevičiūtè A., Veteikis D. 2012. Renatūralizacijos pokyčiai Lietuvos kraštovaizdyje 19952010 m. Geografija. 48(2): 132-144.

15. Banski J., Marcin M. 2016. Classification of rural areas in Poland as an instrumental of territorial policy. Land Use Policy. 54: 1-17.

16. Basalykas A. 1986. Kraštovaizdis - geosisteminès organizacijos sudètingèjimo etapai. Geografijos metraštis. 22-23: 32-39.

17. Bauža D. 2005. Žemenaudos kaita Vilniaus mieste XX amžiuje. Geografijos metraštis. 38(2): 65-71.

18. Bauža D., Baužienè I. 2008. Evaluation of landscape changes in Lithuania in the second half of the 20th century. Geografija. 44(2): 28-35.

19. Bezemer D. J., Stanikunas D., Zemeckis R. 2006. Decline of corporate enterprises in transitional agriculture: evidence from Lithuania. Comparative Economic Studies. 48: 156-182.

20. Bykovienė A., Pupka D., Aleknavičius A. 2014. Žemès ūkio naudmenu ploto apskaita ir pokyčių analizè Lietuvoje. Žemès ūkio mokslai. 21(4): 250-264.

21. Braukaitė S. 2013. Kelmés rajono savivaldybès žemenaudos struktūros kaita 1999-2010 m.: bakalauro darbas. Vilnius: VU Geografijos ir kraštotvarkos katedra.

22. Brazauskas V. 1958. Rytų Lietuvos žemès ūkio naudmenų transformavimo ir teisingo panaudojimo klausimu. Geografijos metraštis. 1: 269-279.

23. Bučienė A., Gadal S., Galinienè J., Gailius V. 2017. Žemaičių Naumiesčio seniūnijos kraštovaizdžio geografinè-retrospetyvinè analizè. Geologija. Geografija. 3(1): 25-36.

24. Burneika D. 2008. Post-soviet transformations of urban space in Vilnius. Annales Geographicae. 41(1-2): 14-25. 
25. Cegielska K., Noszczyk T., Kukulska A., Szylar M., Hernik J., Dixon-Gough R., Jombach S., Valánszki I., Kovács K. F. 2018. Land use and land cover changes in post-socialist countries: some observations from Hungary and Poland. Land Use Policy. 78: 1-18.

26. Čeičys J. 1957. Dirvožemiu melioracija. Vilnius. $53 \mathrm{p}$.

27. Česnavičius D. 1999. Žemès naudojimo tyrimų problemos. Tiltai. 2: 87-96.

28. Česnulevičius A., Lumpickaitė R., Jurevičienè I. 2005. Žemėnaudos struktūros kaita ir jos ịtaka agrarinių kraštovaizdžių geodinaminiam stabilumui (Skiemonių seniūnijos pavyzdžiu). Geografijos metraštis. 38(1): 80-89.

29. Džermeika K. 2008. Agrarinio kraštovaizdžio kaita Užnemunejje 1990-2005 metais (Šeimenos seniūnijos pavyzdžiu): bakalauro darbas. Vilnius: VU Geografijos ir kraštotvarkos katedra.

30. Eitmanavichiene N. 1976. Izmenenie ploshchadi zemelnukh ugodii vlandshaftakh Litvy (1865-1965 gg.) [Changes in the pattern of stretches of cultivated land, meadows and forest in the Lithuania landscapes 1865-1965)]. Geographia Lithuanica: 287-291 [rusų k., santrauka anglu k.].

31. Eitmanavičienè N. 1981. Istorinè geografija. Geografijos metraštis. 19: 157-162.

32. Eitmanavichiene N. 1984. Osvoennost differtsirovannoi teritorii Litvy v XVI v [Man impact on Lithuania's landscape according to the 16th century data]. Geographia Lithuanica: 174-179 [rusų k., santrauka anglų k.].

33. Eitmanavičienè N. 1994. Lietuvos landšaftų struktūros kaita 1865-1965 metais. Geografijos metraštis. 28: 335-355.

34. Eringis J., Milius J. 1976. Vidurio Lietuvos lygumos žemévaldos bruožai (pagal $1554 \mathrm{~m}$. Upytès valsčiaus inventorių). Geografinis metraštis. 14: 123-132.

35. Galvydytė D. 1973. Kai kurie Rytų Lietuvos kalvoto kraštovaizdžio vienkiemių išsidėstymo dèsningumai. LTSR aukštụjų mokyklų mokslo darbai. Geografija ir geologija. 10.

36. Gaudèšius R. 2011. Sustainable land consolidation in Lithuania - the second wave of land reform. Environmental Research, Engineering and Management. 3(57): 39-45.

37. Gulbinas J. 2011. Meškuičiu seniūnijos kraštovaizdžio struktūros kaitos analizé (XIX a. pab. XXI a. pr.): bakalauro darbas. Vilnius: Geografijos ir kraštotvarkos katedra.

38. Gutman G., Radeloff V. (Eds.). 2017. LandCover and Land-Use Changes in Eastern Europe after the Collapse of the Soviet Union in 1991. Springer International Publishing, Cham.
39. Hartvigsen M. 2014. Land reform and land fragmentation in Central and Eastern Europe. Land Use Policy. 36: 330-341.

40. Ivavičiūtè G. 2017. Analysis of damaged land changes in Klaipeda county of Lithuania. Rural and Environmental Engineering, Landscape Architecture. 2: 180-186.

41. Jankauskaitė M., Veteikis D. 2010. On the problem of territorial distribution of sample areas for landscape monitoring purposes. Journal of Environmental Engineering and Landscape Management. 18(3): 234-241.

42. Jankauskaitè M., Veteikis D. 2011. Experience analysis and sample distribution problems in local level landscape monitoring. Environment. Technology. Resources. Proceedings of the 8th International Scientific and Practical Conference, June 20-21, Rezekne. 31-37.

43. Jankauskaite M., Veteikis D. 2013. Changes of landscape spatial structure as a result of transformation of land-ownership. Environment. Technology. Resources. Proceedings of the 9th International Scientific and Practical Conference, June 20-22, Rezekne. 28-32.

44. Janušaitè R. 2016. Kraštovaizdžio komponentu struktūros kaita Šešuvies upés baseine 19502015 metais: bakalauro darbas. Vilnius: VU Geografijos ir kraštotvarkos katedra.

45. Jaskovikaite E. 2005. Vaginiu formy dinamika kintančios žeménaudos sąlygomis (Varžuvos ir Kairènés upiu pavyzdžiu): bakalauros darbas. Vilnius: VU Bendrosios geografijos katedra.

46. Jakutyte E. 2006. Apgyvendinimo ir agrarinio kraštovaizdžio raida Kèdainiu rajone: bakalauro darbas. Vilnius: VU Bendrosios geografijos katedra.

47. Jankaitis L. 2013. Aplinkkeliu buferiniu zony žemènaudos struktūros kaita Lietuvoje: bakalauro darbas. Vilnius: VU Geografijos ir kraštotvarkos katedra.

48. Jepsen M. R., Kuemmerle T., Müller D., et al. 2015. Transitions in European land-management regimes between 1800 and 2010. Land Use Policy. 49: 53-64.

49. Jokubaitytè D. 2003. Žemès naudojimas Kurtuvenu regioniniame parke. Vandens ūkio inžinerija. 22(44); 2: 174-176.

50. Jukna L., Veteikis D. 2010-2011. Žemès dangos natūralumo / dirbtinumo įvertinimas agrariniame kraštovaizdyje. Annales Geographicae (Geografijos metraštis). 43-44: 85-95.

51. Kaplan J. O., Krumhardt K. M., Zimmermann N. 2009. The prehistoric and preindustrial deforestation of Europe. Quaternary Science Reviews. 28: 3016-3034.

52. Kavaliauskas P. 1992. Metodologiniai kraštotvarkos pagrindai. Vilnius. 
53. Kavaliauskas P. 1997. Agrarinio kraštovaizdžio formavimo dokumentų Lietuvoje retrospektyvinè analizè. Geografijos metraštis. 30: 234-239.

54. Kavaliauskas P., Veteikis D. 2004. Theoretical and applied aspects of landscape technogenic morphology. Geografija. 40(2): 11-16.

55. Kavoliute F. 1993. Pastabos apie Lietuvos kraštovaizdžio renatūralizaciją. Geografija. 29: 61-66.

56. Kavoliutė F. 1994. Svarbiausieji Lietuvos kraštovaizdžio raidos bruožai holocene. Geografija. 30: 28-34.

57. Kavoliutė F. 1995. Rèžinès žemènaudos kraštovaizdžio bruožai. Geografija. 31: 49-54.

58. Kavoliutė F. 1996. Lietuvos kaimų kaita XX a. Geografijos metraštis. 29: 289-300.

59. Kavoliutè F., Veteikis D., Jukna L. 2014. Spatial structure of agrarian landscape as a cultural value in Lithuanian state parks. In: Pablo Vidal-Gonzalez (Ed.). Landscape Anthropology in European Protected Areas. University of Stavanger report. 75-84.

60. Kolupaila S. 1954. Melioracijos darbai okupuotoje Lietuvoje. Draugas. Nr. 278. Čikaga.

61. Kraštovaizdžio struktūros pokyčiu probleminiuose arealuose vertinimas vietiniu lygmeniu. 2008. Vilnius: Geologijos ir geografijos institutas.

62. Kraštovaizdžio struktūros pokyčiu probleminiuose arealuose vertinimas vietiniu lygmeniu. 2015. Vilnius: Geologijos ir geografijos institutas.

63. Kriaučiūnaitè-Neklejonovienè V., Rekus D., Daukšys M., Kurtinaitytè A. 2015. State and conditions of the amateur garden territories: land use and management tendencies in Lirhuania. 7th International Scentific Conference Rural Development 2015: Towards the Trasfer of knowledge, Innovations and Social Progress.

64. Kudulytė J. 2016. Agrariniu struktūrų raida Lietuvoje XXI amžiaus pradžioje: bakalauro darbas. Vilnius: VU Geografijos ir kraštotvarkos katedra.

65. Kuemmerle T., Levers Ch., Erb K., Estel S., Jepsen M. R., Müller D., Plutzar Ch., Stürck J., Verkerk P. J., Verburg P. H., Reenberg A. 2016. Hotspots of land use change in Europe. Environment Research Letters. 11: 064020.

66. Kuliešis G., Šalengaitè D. 2010. Apleistos žemès Lietuvoje: problemos, galimi sprendimo būdai. Management theory and studies for rural business and infrastructure development. 5(24): 116-127.

67. Kuliešis G., Šalengaitė D., Kozlovskaja A. 2011. Apleista žemè: problemos ir sprendimo būdai.
Mokslo studija. Vilnius: Lietuvos agrarinès ekonomikos institutas.

68. Kuncaitè G. 2003. Žemès naudojimas Europos Sajungoje ir Lietuvoje. Vandens ūkio inžinerija. 22(44); 2: 189-195.

69. Kuzmaitė J. 1979a. Bažnytinè žemėvalda Žemaitijoje XV-XVIII amžiais (1. Struktūra, dydis, pajamos). Lietuvos TSR Mokslų akademijos darbai. A ser. 1: 53-64.

70. Kuzmaitė J. 1979b. Bažnytinè žemèvalda Žemaitijoje XV-XVIII amžiais (2. Ariamoji žemè). Lietuvos TSR Mokslų akademijos darbai. A ser. 4: 105-116.

71. Mačiulytė J. 2006. Lietuvos kaimiškų teritorijų kaita po nepriklausomybės atkūrimo. Geografijos metraštis. 39(2): 5-14.

72. Mačiulytė J., Veteikis D., Šabanovas S. 2012. Recomposition of rural space in Lithuania since the restoration of independence. Acta Scientiarium Polonorum. Administratio Locorum. 11(3): 167-183.

73. Mališauskas V. 1961. Lietuvos TSR žemès ūkio naudmenos ir ju kokybès gerinimo ekonominio efektyvumo apskaičiavimas. Lietuvos TSR Mokslu akademijos darbai. A ser. 2: 67-80.

74. Matulevičius A. 1997. Ragainès apskrities XVIII a. pirmosios pusès gyventojų tautinė sudètis ir žemėnauda. Iš: Lietuvos sienų raida. 2 tomas. Vilnius. 385-397.

75. Milius J. 1974. Lietuvos žemèveikslių ypatybės gamtinių landšaftų tipuose. Geografija ir geologija. 11: 83-92.

76. Milius J. 1976. Zemelnye ugodya v problematike kraeustroistva [Lands in the problematics of land utilization system]. Geographia Lithuanica: 211-214 [rusų k., santrauka anglų k.].

77. Milius J. 1979. Lietuvos kraštovaizdžio pasikeitimai pokario socialiniu ūkiniu pertvarkų ìtakoje. Geografinis metraštis. 17: 37-44.

78. Milius J. 1981. Žemès ūkio geografija. Geografijos metraštis. 19: 163-169.

79. Milius J. 1983. Prirodno-ekologicheskiy faktor v izuchenii zemelnykh ugodii Litovskoi SSR. Neodnorodnost landshaftov i nrirodopolzovaniya. Maskva. 65-70 [rusu k.].

80. Milius J. 1984a. Žemès naudmenos ir Lietuvos agrarinio kraštovaizdžio tyrimo problematika. Geografija. 20: 39-47.

81. Milius J. 1984b. Uzichenie zemelnukh ugodnii $\mathrm{v}$ aspekte geoekologii i monitoringa [The farming lands: geoecological and monitoring aspects]. Geographia Lithuanica. 191-197 [rusų k., santrauka anglų k.].

82. Milius J. 2009. Lietuvos žemèveikslių statistika (retrospektyvinė apžvalga). Geografija. 36(2): 90-93. 
83. Milius J. 1997. Žemèvalda Lietuvoje $1930 \mathrm{~m}$. Žemètvarka ir melioracija. 2(3): 79-81.

84. Milius J., Ribokas G. 2004. Žemèveikslių apskaitos statistinès ypatybès: kaita ir dabarties problemos. Geografijos metraštis. 37(1-2): 175-183.

85. Milius J., Ribokas G. 2008. Dirvonai Lietuvos XX ir XXI amžių laukuose. Geografija. 44(1): $9-16$.

86. Orlonas L. 2014. Agrarinio kraštovaizdžio sklypinès saskaidos kaita 1995-2013 m. (Rokiškio rajono savivaldybes pavyzdžiu): magistro darbas. Vilnius: VU Geografijos ir kraštotvarkos katedra.

87. Orlonas L., Veteikis D. 2016. Agrarinio kraštovaizdžio sklypinès sąskaidos kaita 19952013 m. (Rokiškio rajono savivaldybès pavyzdžiu). Geografija. 2: 14-25.

88. Peleckis P. 1989. Pro peizazh i ... melioraciyu. Sovestkaya Litva. Sausio 4 d. [rusų k.].

89. Petrokienė L., Ribokas G. 1996. Žeménaudos ypatybès aktyvaus karsto zonoje. Geografijos metraštis. 29: 7-19.

90. Piskunovas V. 2015. Žemènaudos struktūros kaita Šalčininku rajono savivaldybejje 19952013 metais: bakalauro darbas. Vilnius: VU Geografijos ir kraštotvarkos katedra.

91. Plieninger T., Draux H., Fagerholm N., Bieling C., Bürgi M., Kizos Th., Kuemmerle T., Primdahl J., Verburg P. H. 2016. The driving forces of landscape change in Europe: a systematic review of the evidence. Land Use Policy. 57: 204-214.

92. Prapiestienè R. 2003. Lietuvos miestų žaliųu plotų kaita laiko atžvilgiu. Geografijos metraštis. 36(2): 108-114.

93. Prishchepov A. V., Radeloff V. C., Bauman M., Kuemmerle T., Muller D. 2012. Effects of institutional changes on land use: agricultural land abandonment during the transition from state-command to market-driven economies in post-Soviet Eastern Europe. Environmental Research Letters. 7: 1-13.

94. Ribokas G., Aidukonytė R. 1998. Lietuvos miestų žemėveiksliai ir jų kaita. Geografijos metraštis. 31: 408-424.

95. Ribokas G. 1999. Lietuvos miestų natūralių ir pusiau natūralių bei urbanizuotų plotų santykių analizè. Geografijos metraštis. 32: 304-313.

96. Ribokas G., Milius J. 2001. Agrarinès žemènaudos transformacijos XX a. sudetinguc ūkinių sąlygu teritorijose. Geografija. 37(2): 65-72.

97. Ribokas G., Milius J. 2007. Turning points in the development of farm lands (case of Lithuania agro territories). Geografija. 43(1): 8-11.
98. Ribokas G., Milius J. 2008. Žemėnaudos struktūros kaita Šiaurès rytų Lietuvoje atkūrus nepriklausomybę. Geografijos metraštis. 40(2): 38-49.

99. Ribokas G., Rukas V. 2006. Mažiau palankių ūkininkauti teritorijų žemènaudos konversijos ypatybès. Geografijos metraštis. 39(1): 60-68.

100. Ribokas G., Zlatkutė A. 2009. Žemènaudos kaita Anykščių rajono savivaldybejje (Viešintų seniūnijos pavyzdžiu). Geografijos metraštis. 42(1-2): 45-54.

101. Ribokas G. 2011. Apleistų žemių (dirvonų) problema retai apgyvendintose teritorijose. Kaimo raidos kryptys žiniu visuomenejje. 2: 298-307.

102. Ribokas G. 2012. Šiaurès rytų Lietuvos žemès naudojimo socialiniai aspektai. Geografijos metraštis. 45: 90-97.

103. Rukas V. 2006. Žeménaudos konversija Rytu Lietuvoje (Ignalinos rajono savivaldybès Vidiškiu kadastrinés vietovés pavyzdžiu): bakalauro darbas. Vilnius: VU Geografijos ir kraštotvarkos katedra.

104. Saiminikaitė S. 2011. Šventosios slènio kraštovaizdžio struktūros kaita XX-XXI a. (atkarpoje tarp Jaros ir Virintos): bakalauro darbas. Vilnius: VU Geografijos ir kraštotvarkos katedra.

105. Samas A. 1972. Kai kurie žemès naudmenų panaudojimo klausimai ir landšaftu kitimo bruožai. Geografija ir geologija. 9: 51-61.

106. Senetra A., Szczepańska A., Veteikis D., Wasilewicz-Pszczółkowska M., Šimanauskienè R., Volungevičius J. 2013. Changes of the land use patterns in the Polish and Lithuanian trans-border rural area. Baltica. 26(2): 157-168.

107. Sinkevičiūtè V., Gudritienè D. 2011. Analysis of rural landscape structure use in Southern Lithuania. Baltic Surveying. 11: 132-137.

108. Stanikūnas D. 1997. Lietuvos nederlingų žemių naudojimo dabartis ir rytdiena: ekonominiai, ekologiniai ir socialiniai aspektai. Žemés ūkis. 8: 3-4.

109.Stravinskienė V., Aleknavičius A., Aleknavičius P. 2015. Ūkių žemès naudojimo perspektyvos Lietuvoje. Žemés ūkio mokslai. 22(4): 216-228.

110. Stravinskienè V., Bajarūnaitè A., Abalikštienè E., Baliavičius G. 2011. Ecological farming in Lithuania. Baltic Surveying. 11: 138-145.

111. Šalkauskienè V., Gudritienè D., Abalikštienè E. 2019. Analysis of the non-productive land use in Lithuania. Land Use Policy. 80: 135-141.

112. Šakinytè N. 2014. Pasvalio rajono žeménaudos struktūros kaita 1999-2013 metais: bakalauro darbas. Vilnius: VU Geografijos ir kraštotvarkos katedra. 
113. Šiupinytė R. 2013. Žemés ūkio naudmenų dinamika Baltijos šalyse atkūrus nepriklausomybę: bakalauro darbas. Vilnius: VU Geografijos ir kraštotvarkos katedra.

114. Šiupinytè R. 2015. Žemès ūkio naudmenu kaitos socioekonomine teritorine analize 20032010 metais: magistro darbas. Vilnius: VU Geografijos ir kraštotvarkos katedra.

115. Šnipaite D. 1968. Vliyanie meliorativnykh meropriyatii na transformaciyu ugodii $\mathrm{v}$ Litovskoy SSR. Voprosy melioracii. 3(11): 86-97 [rusuc k.].

116. Totorytè V. 2014 Lèvens upés baseino žeménaudos pokyčiai 1950-2010 m.: bakalauro darbas. Vilnius: VU Geografijos ir kraštotvarkos katedra.

117. Tamulaitis B. 1987. Melioracija ir gamta. Vilnius. $44 \mathrm{p}$.

118. Tiknius A. 1988. Okhrana struktury landshaftov pri melioracii zemel v Litovskoy SSR. Iš: Problemy ochrany prirody $v$ agropromyšlennom komplekse. 133-134 [rusų k.].

119. Truska L. 1985. Žemèvaldos ir feodalų klasès struktūra Lietuvoje XVIII a. pabaigoje (3. Užnemunè 1775-1790 m.). Lietuvos TSR Moksly akademijos darbai. A ser. 1: 98-108.

120. Üsas A. 1966. Osushenie zemel v Litovskoy SSR. Ekonomika selskovo khoziaistva. 7: 13-15 [rusu k.].

121. Velička J. 1972. Melioratoriai keičia kraštovaizdị. Iš: Gamta ir žmogus. Vilnius. 19-28.

122. Verkulevičiūtè-Kriukienè D., Bučienè A., Beteika L. 2018. Rural landscape status, func- tions and human factors in the transboundary Nemunas delta region. Area. 50(3): 353-363.

123. Veteikis D., Jukna L., Jankauskaitè M. 2016. Kraštovaizdžio struktūros pokyčių probleminiuose arealuose vertinimas vietiniu lygmeniu 2015-2016. Europos ekonomines erdves finansinio mechanizmo programos LT02 „Integruotas jūros ir vidaus vandenų valdymas" viešinimo renginys. Prieiga per internetą: http://gamta.lt/ files/L.Jukna.pdf [žiūrèta 2018-11-21].

124. Veteikis D., Kavaliauskas P. 2014. Kraštovaizdžio kitimo tendencijos. Lietuvos nacionalinis atlasas. 1: 123 [žemèlapis].

125. Veteikis D., Šabanovas S., Jankauskaitė M. 2011. Landscape structure changes on thecoastal plain of Lithuania during 1998-2009. Baltica. 24(2): 107-116.

126. Viltrakis M. 2013. Žemènaudos struktūros pokyčiai Vilkaviškio rajono savivaldybejje 19992010 metais: bakalauro darbas. Vilnius: VU Geografijos ir kraštotvarkos katedra.

127. Vitkutè J. 2017. Mapping the Trajectories and Intensity of Agricultural Land-use in PostSoviet Temperate Eastern Europe. Copenhagen: University of Copenhagen Faculty of Sience. [Master thesis].

128. Zlatkutė A. 2010. Agrarinio kraštovaizdžio kaita Lietuvoje 1919-2009 metais: bakalauro darbas. Vilnius: VU Geografijos ir kraštotvarkos katedra.

129. Žemés dangos duomenu bazé CORINE. Prieiga per internetą: https://aplinka.lt/zemes-dangos-duomenu-baze-corine-landcover 
Darijus Veteikis, Eglè Piškinaitė

\section{GEOGRAPHICAL STUDY OF LAND USE CHANGE IN LITHUANIA: DEVELOPMENT, DIRECTIONS, PERSPECTIVES}

\section{Sum mary}

Land use (land with a purpose provided by man) and land cover (physical expression of land use on the surface of the land) in geography science are considered to be objects of research relevant to the social and economic issues, landscape morphology and functioning, environmental protection. Observations of land use/ land cover (LULC) changes allow not only to recognize the regularities of landscape development, but also to evaluate the extent of factors influencing the landscape, to predict possible directions of landscape change and to prevent destructive processes.

Governmental institutions of Lithuanian Republic have acquired and are still developing many tools for LULC monitoring that is one of the directives following from European Landscape Convention (2000) including participation in CORINE land cover projects, monitoring LULC in local level using sample areas (100 units, squares of $2.5 \mathrm{~km}^{2}$ distributed in different landscape types), constant almost biennial or annual update of georeference data of LULC in the scale of $1: 10,000$ using aerial photography.

Research on land-use structure in the country's research institutions has no unified coordination, and there is a great variety of chronological, geographical and thematic work that this article aims to review and summarize. This article also aims to identify and carry out territorial dissemination of research and identify areas for which LULC surveys should be relevant and draw attention to prospective LULC research trends.

During the last 60 years, Lithuanian researchers' work on LULC and its change reveals 1) the perception of the impact of political, social, economic processes, and their breaking points on the change of LULC, the most important in the 20th and 21 st centuries, and 2) concerns of LULC change on the sustainability of the landscape and the preservation of its cultural layer. The number of works grew steadily, the thematic diversity and the number of works representing thematic themes also spread proportionally.

Performed LULC change surveys can be classified according to various parameters: scale, direction of research, territorial and chronological coverage. In the last two decades, the information technology leap, facilitating LULC structure surveys from cosmic and aerial imagery, has also accelerated spatial geographic information processing, greatly increasing the number of land-use surveys focused on land-use changes that have occurred since independence. The historical studies of the far past take up a small part of the research because not only of the lack of historical, especially cartographic sources, but also of methodological basis for the correct analysis of the latter (Figs. 1 and 2).

The set of local LULC change surveys is complemented by student final theses, but overall, local research is carried out without unanimous coordination, resulting in a great chronological, geographical and thematic variety of works. The purposefulness of the research could be formed by developing a methodology to use the results of these studies as benchmarks, examples of which would be used to summarize the country's LULC situation.

In the context of European research on LULC change, adopting the suggestions of Plieninger et al. (2016), it is suggested to include in the geographic LULC surveys of Lithuania low-investigated types and locations of landscapes, to identify key factors of landscape change, to develop methods for quantitative analysis of landscape change, to carry out research covering longer historical periods and cross-border regions, to look for and take into account delicate and new landscape processes, to explore stable, low-changing land-use structures, to identify factors that are resistant to external influences.

Keywords: land use, land use structure, land cover, change in land use structure, landscape change 